\title{
The international community and post-war reconciliation in Africa: A case study of the Sierra Leone Truth and Reconciliation Commission
}

\section{Proscovia Svärd ${ }^{\star}$}

\section{Abstract}

The decade-long armed conflict and political unrest in Sierra Leone deeply affected the civilian population. Since the end of the war in 2002, the government of Sierra Leone and the international community have been involved in peacebuilding activities, national reconciliation and reconstruction. The reconciliatory process necessitated the setting up of a Truth and Reconciliation Commission (TRC) which was also a product of the Lomé Peace Agreement between the Government of Sierra Leone and the now defunct Revolutionary United Front (RUF). The international community invested US\$ 4,6 million in the Sierra Leone TRC mission. The TRC examined the causes of the war, human rights violations and the role played by foreign actors. This paper analyses the TRC as an internationally driven process to enhance reconciliation, peace, development and democracy in Sierra Leone. It also evaluates the impact of the implementation of the recommendations of the TRC. Beyond this, it makes

* Proscovia Svärd is a Ph.D. Candidate at the Department of Information Technology and Media, Mid-Sweden University, Härnösand, Sweden. She has previously worked as a Research Administrator for the programme on Post-Conflict Transition, the State and Civil Society in Africa, co-ordinated by Dr. Cyril Obi, at the Nordic Africa Institute, Uppsala, Sweden. 


\section{Proscovia Svärd}

some suggestions on how the international community can better promote transitional justice and the peacebuilding process by supporting local initiatives and promoting national ownership for sustainability.

\section{Introduction}

Sierra Leone is one of the few countries that have pursued a dual approach to transitional justice. The Special Court for Sierra Leone was established to try persons who bear the greatest responsibility for war crimes and crimes against humanity whilst the Truth and Reconciliation Commission (TRC) pursued forgiveness and reconciliation (Sawyer and Kelsall 2007:37). The focus of this paper is on the TRC as an instrument that was financed by the international community in order to implement some transitional justice measures and promote post-war reconciliation in the country. The decade-long civil war, characterised by abduction and mutilation of civilians, destruction of properties, rampant rape and sexual abuse of women and young girls and the recruitment of children into irregular armed groups, necessitated the establishment of a TRC to heal those wounds and build a democratic state (Schabas 2005:129). The ethnic, regional and violent politics of the 1970s paved the way for the Sierra Leonean crises and disintegration of the society. Ethnic and regional politics facilitated the north-south divide and the uneven distribution of resources (Keen 2005). Regardless of the rich natural resources like diamonds, gold, bauxite, iron ore, coffee, cocoa and palm kernels, Sierra Leone has remained a poor country. Presidents like Siaka Stevens were more interested in building a personal fortune and power base than in the general development of the country. The politics of patronage and intimidation created resentment against corrupt politicians (Keen 2005:26).

According to international law, governments have an obligation to bring perpetrators of war crimes and crimes against humanity to justice. Article 26 of the African Charter also encourages governments to carry out an official inquiry into human rights abuses and to establish national institutions to protect human rights (Human Rights Watch 1991:1-4). Transitional governments should opt for full accountability in order to deter the repetition of violations. Avruch and 


\section{A case study of the Sierra Leone Truth and Reconciliation Commission}

Vejarano (2002:42) argue that accountability is a prerequisite for democratic transition. TRCs therefore help new governments to establish a foundation on which to build legitimacy by espousing democratic ideals, the rule of law, formal legal equality and social justice (Brahm 2006:6). The TRC was able to examine the history of the conflict through a victim-centred truth-seeking process with a concentration on the issues of children. A just and economically viable Sierra Leone was to depend on a deep understanding of the country's past (Conflict Management and Development Associates et al. n.d.:22). Justice and truth commissions are key processes for achieving reconciliation and peace (Othman 2005:249). The TRC was to produce an impartial historical record of the conflict and atrocities committed against the civilian population (Sawyer and Kelsall 2007:37). The status of the country after the conflict speaks to the fact that the help of the international community to address the gross violations of human rights and international humanitarian law was required.

The restoration and establishment of the rule of law, peace and security and the eradication of impunity is one way to promote a democratic society (Othman 2005:250). Reconciliation is crucial to the process of sustainable peacebuilding. However, can people reconcile by recounting the trauma to which they have been subjected? And is this enough to enable them to embark on the democratisation process? It is also argued in the literature on TRCs that it is important to unearth the truth if there is to be any reconciliation (Hayner 2002; Skaar, Gloppen and Suhrke 2005). An important question that should be put before the proponents of TRCs is whether the truth is essential if it does not lead to some kind of punishment or to improvements in the social and economic justice. The past cannot be forgotten since it is very important for the future and therefore needs to be documented for posterity. But what about communities that believe in forgetting and that equate the recounting of past atrocities to the opening up of old wounds? What about the traditional mechanisms of conflict resolution that some communities have traditionally used to resolve conflicts? (Sesay 2007:4344). These are complex issues which, given the nature of the war, are hard to address, but a war-weary population has expectations and needs to see quick economic recovery and development that can generate employment, social 


\section{Proscovia Svärd}

services like education, health, electricity and water, and the reconstruction of infrastructure.

This paper analyses the TRC as an internationally driven process for the democratisation of Sierra Leone through truth and reconciliation. It also evaluates the impact of the implementation of the TRC on the consolidation of democracy in Sierra Leone. Another aspect relates to the national ownership of the transitional justice process, and how much access Sierra Leoneans have had to the TRC findings. The paper is divided into an introduction, a historical background of the Sierra Leonean conflict, an analysis of the TRC process and its aftermath, a conclusion and some recommendations.

\section{Method}

The study is based on a combination of primary and secondary data as well as the author's personal observations. Data on the TRC process and post-conflict development processes were collected from unstructured interviews with students, researchers, activists and ordinary people during the author's visits to Freetown, Sierra Leone, in September 2006 and in March and September 2007. A literature review on the topic was also undertaken.

\section{A historical background of the Sierra Leonean civil war}

Sierra Leone is a small West African State with over 4,5 million people. It gained independence in 1961 and has since had a succession of corrupt leaders. Sir Milton Margai, the first President of independent Sierra Leone, managed to bring about a steady development in the country until the long (1968-1985) and autocratic rule of Siaka Stevens of the All People's Congress (APC). Stevens' rule led to authoritarianism, corruption and patrimonialism, depriving the majority of Sierra Leoneans of basic social services (Sesay 2003). The ineffectual leadership of Momoh, Stevens' successor, coupled with mass social disaffection, plunged the country into war. The insurgency of the 23rd March 1991 by the Revolutionary United Front (RUF), led by Corporal Foday Sankoh, was, according to Ukeje (2003:113), a by-product of the Liberian civil war. Charles Taylor, leader of the former National Patriotic Front of Liberia (NPFL), was considered a destabilising force in the region and a sponsor of the RUF (Afrol 


\section{A case study of the Sierra Leone Truth and Reconciliation Commission}

News n.d.). The subsequent years gave way to a complicated and protracted conflict, fuelled by diamonds that were supposed to serve as a blessing to the country. The RUF walked in the footsteps of those it had intended to overthrow and was devoid of ideology (Schabas 2005:130). It indiscriminately amputated limbs, abducted women and children, recruited children as combatants, raped and sexually abused women and children, carried out gratuitous killings and cannibalism, and destroyed villages and towns (Conflict Management and Development Associates et al. n.d.).

In March 1999, peace negotiations started, and culminated in a power sharing agreement, the Lomé Peace Agreement, signed on 7 July 1999 between the RUF and the SLPP government (Lomé Accord 1999; Schabas 2005:130). This agreement provided amnesty to the perpetrators of atrocities. However, the then Special Representative of the United Nations (UN) Secretary-General, Francis Okello, insisted that the amnesty was not to apply to crimes against humanity and war crimes. The Lomé Agreement paved the way for the establishment of a Truth and Reconciliation Commission (Schabas 2005:130). The TRC was established as a result of the need for reconciliation - as agreed in the Lomé Agreement by the parties involved. In addition, it was sanctioned by an act of parliament. Since accountability is a prerequisite for democratic transition, the role played by truth commissions in unearthing the truth is of importance to stability, peace and the democratisation process of post-conflict societies (Hayner 2002:24).

\section{Analysis of the Truth and Reconciliation process}

The purpose of setting up a TRC was to address the past, heal the wounds of the victims and enable communities to reconcile. Through reconciliation, a more united society would emerge to engage in the reconstruction work of promoting long-term peace. Since the cause of the war was largely the uneven distribution of resources (Keen 2005), Kabbah's government was expected to usher in a new democratic dispensation that was to deliver the dividends of democracy, including the basic amenities and freedom of expression. 


\section{Proscovia Svärd}

\section{Democratisation}

The TRC process was supposed to lead to a democratic development that would address the root causes of the conflict. The war in Sierra Leone was a result of bad governance, uneven distribution of resources and institutional failure to guarantee the citizens security, livelihood and democratic participation in decision-making processes (Conflict Management and Development Associates et al. n.d.). This article, therefore, looks at popular democracy which puts the needs, interests and voices of the electorate at the centre of the process. Popular democracy operates on the principles of equal sharing of and access to resources, equal rights regardless of gender, ethnicity, disability, nationality and sexuality, and would therefore be appropriate to the Sierra Leonean case. Participatory decision-making is the key to the involvement of all citizens, especially the poor (Scott and Katz-Fishman 2004:1). Democracy is internationally supported because it is a means by which development is achieved. Where there is development, there are hopes for stability, order and peace. Rudebeck (2002:7) posits that 'democratisation in any given country implies in the first place, equalisation of power to control those developmental resources', which can probably only be controlled from within that country. Scholars such as Sawyer (2004:109) believe that the sustainability of democracy in Africa should be grounded in the common humanity of all citizens. The process of democratisation can be conflict-preventing and -resolving and can enhance productive discourses that would promote enlightenment and problemsolving capabilities (Sawyer 2004:112). According to the 2006 publication of the International Institute for Democracy and Electoral Assistance (International IDEA 2006:122), democratisation processes should include elections that give people a voice to advocate for their interests and needs, promote universal education, the flow of communication and the spread of knowledge, prioritising public goods such as education, health, job training, a clean environment and the rule of law. Failure for democracy to address justly distributed social-economic development undermines human security (International IDEA 2006:124). The TRC was therefore set up to address the social injustices that caused the conflict. 


\section{A case study of the Sierra Leone Truth and Reconciliation Commission}

In a post-conflict society, people need to regain trust in government institutions because as Rothstein (2005:21) postulates, 'the more trust a society has, the more democratic it is, the better governed it is, the more economic prosperity it will have'. Competence and impartiality are key if people are to develop trust in institutions (Rothstein 2005:25). There has to be confidence in courts, the police, universities, public schools and public health care systems (Rothstein 2005:24). The export of ideal rights and institutions must make sense within contexts of people, interests and power relations (Törnquist 2003:32). The democratisation of a society should therefore promote political equality and popular capacity to enable people to use their democratic rights and institutions (Törnquist 2003:34). Transitional justice and democracy should lead to improved living conditions for the population and socio-economic development (International IDEA 2006:125). In this same publication it is stated that the populations of many countries are disappointed by democratic systems that cannot deliver basic human security needs (International IDEA 2006:115). In order to build and to sustain peace, democratic systems should incorporate the following core values:

1. Institutional arrangements of power sharing

2. Checks and balances for the responsible and accountable use of power

3. 'Process options' for a public policy which meets local needs for development and human security

4. Equality in human rights and political participation

Democracy is intended to function as the ultimate conflict management system for a country. However, it is threatened when human rights are violated, when there is lack of human security and when power and resources are concentrated in the hands of a chosen few (International IDEA 2006:50-53). Analysing the TRC in Sierra Leone, Sesay highlights the need to improve the lives of the people in order to hasten the reconciliation process. He is of the view that reconciliation is a process that is linked to government policies and structural macro-level reforms to address the causes of conflict (Sesay 2007:16). 


\section{Proscovia Svärd}

\section{The Truth and Reconciliation Commission (TRC)}

The Sierra Leone TRC was established on the basis of the provisions of Article 26 of the 1999 Lomé Peace Agreement between the Government of Sierra Leone and the now defunct Revolutionary United Front (RUF), and was sanctioned by an act of parliament - the TRC Act of 2000. The Sierra Leonean TRC Act called for the commission 'to create an impartial historical record of violations and abuses of human rights and international humanitarian law related to the armed conflict in Sierra Leone from the beginning of the conflict in 1991 to the signing of the Lomé Peace Agreement, to address impunity, to respond to the needs of the victims, to promote healing and reconciliation and to prevent a repetition of the violations and abuses suffered' (Hayner 2004:2).

The investigation was to further reveal whether the committed atrocities were planned or authorised by any of the governments, factions or individuals. Since the Sierra Leonean war was greatly influenced by external factors like the war in Liberia with warlord Charles Taylor in the lead, the TRC looked at the role played by foreign actors too. The Commission shared the notion of the South African Truth and Reconciliation Commission report that unless the truth is exposed, the possibility of reconciliation, reunification and trust remains elusive (Truth and Reconciliation Commission of South Africa 2003). The Commission had seven commissioners, four of whom were Sierra Leoneans, three international commissioners (Dumbuya 2003:20-21) and other staff that were involved in its work. The Commission was principally funded by the United States of America, the United Kingdom, Germany, Ireland, the Netherlands, Canada and the European Union (Schabas 2005:133), with the Office of the United Nations High Commissioner for Human Rights (OHCHR) in Geneva serving as the main channel of the donor funds. The Commission became a mere implementer, while the OHCHR served as the Project coordinator and controller of funds for the Commission's work. The TRC's work was to last between a year and eighteen months with a budget of US\$ 4,6 million, reduced from the original figure of US\$ 10 million. ${ }^{1}$

1 E-mail interview with the Chairperson of the TRC, Bishop Joseph C. Humper, March 2006. 


\section{A case study of the Sierra Leone Truth and Reconciliation Commission}

\section{International intervention}

The TRC in Sierra Leone was a transitional justice mechanism that was supported by the international community to the amount just mentioned. Since external assistance in post-war reconstruction was reduced after the most pressing issues had been addressed, the sustainability of the concluded activities requires a follow-up institution. The government ought to have the capacity to further pursue what has been achieved with the help of the international community (Sesay 2007:50, 53). Although the international community supports transitional justice, Brahm is of the view that its involvement in TRCs can have some negative effects due to lack of knowledge of the domestic environment (Brahm 2006:6). Even though the work of the TRC was appreciated by some of the respondents, there was a view that some communities wanted to exercise their traditional ways of dealing with conflicts. Interviews conducted in Sierra Leone in September 2006 revealed that lack of possibilities to use traditional ways impacted negatively on the reintegration of some of the perpetrators into their communities. ${ }^{2}$ In one case it was even said that the failure to embrace traditional mechanisms failed the re-integration of some of the ex-combatants into their communities (Sesay 2007:42-43). Sesay highlights this point and argues that local mechanisms for reconciliation should be used as much as possible, since they are cheaper and more easily accepted by the people (Sesay 2007:42-43). The Sierra Leonean TRC depended heavily on the international community for funding. Where the pledged funding was not delivered, rehabilitation programmes for amputees and victims of sexual violence and children could not be implemented as planned (Sesay 2007:49). Sesay contends that even though the international community has already spent a lot of money on the TRC, it will need to inject more financial assistance if the transition from insecurity to genuine peace and development is to be achieved.

\section{The recommendations of the TRC}

The recommendations of the TRC were designed to promote a new Sierra Leone where human dignity, tolerance and respect of all people's rights would be

2 Interview with the Executive Director of Campaign for Good Governance, March 2006, Freetown, Sierra Leone. 


\section{Proscovia Svärd}

established. This new society would enhance vibrant democracy where all citizens would be treated equally before the law (Conflict Management and Development et al. n.d.:117). The legacies of the conflict were to be confronted to enhance the need for 'tolerance, not for prejudice: a need for acknowledgement and accountability, not for recrimination: a need for reparation, not for retribution; a need for community, not for victimisation; a need for understanding, not for suspicion; and a need for reconstruction, not for greed' (Conflict Management and Development et al. n.d.:117). The Sierra Leone People's Party (SLPP) government was to faithfully implement the recommendations through the state institutions and also facilitate the recommendations directed at other bodies (Conflict Management and Development et al. n.d.:117). It was also stated that after the publication of the TRC report, a committee or an institution that would include representatives of the Moral Guarantors of the Lomé Peace Agreement would be formed to monitor the government's implementation of the TRC recommendations.

The Commission also recommended that its findings be widely disseminated to the people. The TRC recommendations were divided into three categories: the Imperative, the Work Towards and the Seriously Consider recommendations. The imperative recommendations were to be implemented as soon as possible. It was further recommended that the parliament should enact an 'Omnibus bill' to address the implementation of the imperative recommendations (Conflict Management and Development et al. n.d.:119). Work Towards meant that the government should work towards the fulfilment of a recommendation and Seriously Consider meant that the TRC wanted the government to seriously consider the recommendation (Conflict Management and Development et al. n.d.:120). The recommendations called for the protection of human rights, establishing the rule of law, improved security services, promotion of good governance, the fight against corruption, the addressing of youth, women and children issues, the promotion of regional integration and unity by external actors, accountability for the proceeds from mineral resources, the building of the national justice system, reparations, reconciliation that included guiding principles and reconciliation activities, a national vision of going forward, archiving of commission documentation, dissemination of the TRC Report 
and the establishment or formation of a Follow-up Committee (Conflict Management and Development et al. n.d.:123-125).

\section{Recommendations Table: Protection of Human Rights}

\begin{tabular}{|l|l|l|l|}
\hline Imperative & Work Towards & $\begin{array}{l}\text { Serious } \\
\text { Consideration }\end{array}$ & Calls On \\
\hline $\begin{array}{l}\text { Enshrine human } \\
\text { dignity as a } \\
\text { fundamental } \\
\text { right in the } \\
\text { Constitution. }\end{array}$ & $\begin{array}{l}\text { Compulsory } \\
\text { human rights } \\
\text { education in } \\
\text { schools, army, } \\
\text { police and judicial } \\
\text { services. }\end{array}$ & $\begin{array}{l}\text { Creation of a } \\
\text { new constitu- } \\
\text { tion for Sierra } \\
\text { Leone. }\end{array}$ & $\begin{array}{l}\text { Judiciary } \\
\text { to adopt a } \\
\text { rights and } \\
\text { values based } \\
\text { approach to } \\
\text { constitutional } \\
\text { interpretation. }\end{array}$ \\
\hline $\begin{array}{l}\text { Abolish the } \\
\text { death penalty. } \\
\text { Commute } \\
\text { pending death } \\
\text { sentences. }\end{array}$ & $\begin{array}{l}\text { Codify Customary } \\
\text { to be in accordance } \\
\text { with Constitution } \\
\text { and international } \\
\text { obligations. }\end{array}$ & $\begin{array}{l}\text { Extend } \\
\text { constitutional } \\
\text { jurisdiction to } \\
\text { other courts. }\end{array}$ & $\begin{array}{l}\text { Judiciary not to } \\
\text { permit unjust } \\
\text { laws and prac- } \\
\text { tices to stand. }\end{array}$ \\
\hline $\begin{array}{l}\text { Release persons } \\
\text { held in Safe } \\
\text { Custody deten- } \\
\text { tion. Never again } \\
\text { resort to Safe } \\
\text { Custody deten- } \\
\text { tion. }\end{array}$ & & $\begin{array}{l}\text { Outlaw } \\
\text { corporal } \\
\text { punishment } \\
\text { throughout } \\
\text { Sierra Leone } \\
\text { society. }\end{array}$ & $\begin{array}{l}\text { Comternational } \\
\text { to Support } \\
\text { a Street Law } \\
\text { programme in } \\
\text { Sierra Leone. }\end{array}$ \\
\hline $\begin{array}{l}\text { No ouster of } \\
\text { Courts' jurisdic- } \\
\text { tion in Public } \\
\text { Emergencies. } \\
\text { Certain rights are } \\
\text { non-derogable } \\
\text { in Emergencies. } \\
\text { Various measures } \\
\text { for the protection } \\
\text { of detainees. }\end{array}$ & & & $\begin{array}{l}\text { Media to } \\
\text { thoroughly } \\
\text { investigate } \\
\text { stories before } \\
\text { publication. }\end{array}$ \\
\end{tabular}


Proscovia Svärd

\begin{tabular}{|c|c|}
\hline $\begin{array}{l}\text { Avoid criminal } \\
\text { sanctions in } \\
\text { sphere of expres- } \\
\text { sion. Limit } \\
\text { criminal sanc- } \\
\text { tions to conduct } \\
\text { aimed at inciting } \\
\text { violence and } \\
\text { lawlessness. }\end{array}$ & $\begin{array}{l}\text { Sierra Leone } \\
\text { Association } \\
\text { of Journalists } \\
\text { and Media } \\
\text { Commission to } \\
\text { be more active } \\
\text { in monitoring } \\
\text { of standards of } \\
\text { journalism. }\end{array}$ \\
\hline $\begin{array}{l}\text { Race and gender } \\
\text { must not be a } \\
\text { consideration in } \\
\text { the acquisition of } \\
\text { citizenship. }\end{array}$ & \\
\hline $\begin{array}{l}\text { Outlaw use of } \\
\text { corporal punish- } \\
\text { ment in schools } \\
\text { and homes. }\end{array}$ & \\
\hline $\begin{array}{l}\text { Repeal sections } \\
27(4)(\mathrm{d}) \text { and } \\
\text { (e) of the } \\
\text { Constitution } \\
\text { which permit } \\
\text { discrimination } \\
\text { against women. }\end{array}$ & \\
\hline $\begin{array}{l}\text { Create a National } \\
\text { Human Rights } \\
\text { Commission } \\
\text { (HRC). Public } \\
\text { and open nomi- } \\
\text { nation process for } \\
\text { commissioners. }\end{array}$ & \\
\hline
\end{tabular}




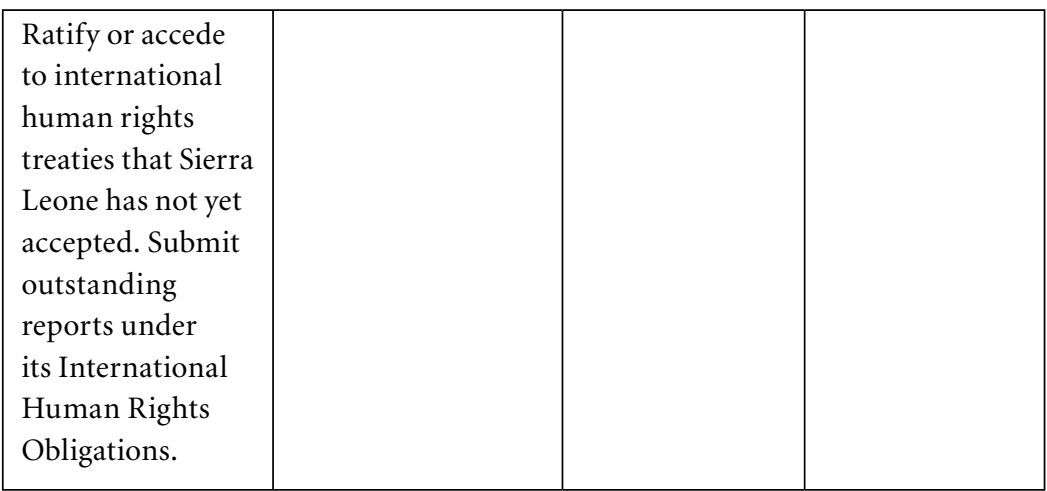

Source: Conflict Management and Development Associates et al. n.d.

The work of the TRC was to enhance reconciliation through the recommendations that it put forward to the SLPP government.

\section{Reconciliation}

In order for post-conflict societies to reconcile and to consolidate democracy, they need to address past atrocities (Gloppen 2005:17). Democratic consolidation builds on national reconciliation and according to Gloppen $(2005: 18,32)$, the five strategies that enhance reconciliation are:

1. Retributive justice where the focus is on justice and perpetrators are held accountable and punished for their crimes.

2. The need to establish the truth through testimonies and institutional mechanisms like truth commissions.

3. Restitution and rehabilitation of victims through the acknowledgment of the physical, psychological and social damages caused by past injustices.

4. Forward-looking reforms through the building of institutions for the prevention of future human rights violations, the promotion of social justice, constitutional and economic reforms, reforms of just apparatus, and the promotion of the education, health and housing sectors.

5. Oblivion through amnesty and public amnesia. 


\section{Proscovia Svärd}

Reconciliation is also about individuals forgiving each other and the mending of the societal social fabric in an effort to peacefully live together. Reconciliation and democracy are therefore intrinsically linked because they are a process through which 'a common set of values are developed and a democratic society can be built' (Gloppen 2005:21). There is, however, a school of thought that coming to terms with the past is easier if the material, physical and other special needs of victims and perpetrators are catered for (Sesay 2007:29). This was the aim of the Sierra Leone TRC, but has that really been achieved? To find out, a representative group of Sierra Leoneans was consulted about the reconciliation process. All the perceptions are not included in this paper but a few voices are represented.

\section{Reconciliation as understood by the citizens}

Among the people interviewed in September 2006, there was a general perception that the TRC was the right platform for people to reconcile even though its work had been stifled by the parallel existence of the Special Court. Given the nature of the conflict wherein many Sierra Leoneans were involved, the neutrality of the TRC was a welcome initiative. Nevertheless, some people believed that a better reintegration of the perpetrators into some communities required an embracement of the traditional mechanisms. An interview with a young Sierra Leonean Master's student revealed that there is much more to reconciliation than unearthing the truth. His response as to whether the TRC process had enhanced healing and reconciliation was, 'Well, I will say no. I will say no because you cannot talk about reconciling victims and perpetrators living within the same community when the victims are still living in appalling conditions. For instance, the man whose house was burnt, if he is still homeless, if he cannot afford basic facilities for his children, he is still thinking of the war days! Whenever he looks at his present plight, his mind is drawn back to what actually caused the problems. So, the point that I am making here is that there is no logical conclusion to this day. So the healing process has not come to its conclusion yet.' ${ }^{3}$ A respondent working with the Special Court was of the view

3 Interview with a Master's Student, Fourah Bay College, University of Sierra Leone, September 2006. 


\section{A case study of the Sierra Leone Truth and Reconciliation Commission}

that healing and reconciliation had not yet taken place because there were still many political, socio-economic problems in the country. He made reference to the TRC recommendations that the government was yet to implement. ${ }^{4}$ However, there was a general consensus among the interviewees that for the healing and reconciliation process to take place the causes of the civil war have to be addressed and the recommendations of the TRC implemented.

Based on the perceptions of the ordinary citizens of Sierra Leone, one would wonder whether the TRC can be judged as a successful process. This, I believe, is a debatable issue because it is hard to achieve genuine peace and development in a situation where the very causes of the conflict still exist. One could also argue that since restorative justice is the foundation of healing and reconciliation (Sesay 2007:50-51), the platform that was offered to the victims and perpetrators through the TRC was a necessity in a country where many people were affected by the conflict. The international community, however, should have continued to support the TRC activities and should have ensured that reparations were paid to the victims. Or, where individual compensation was an impossible task, that communities were compensated as far as possible through the construction of facilities that would ease their daily constraints and restore their dignity. Sesay (2007:49) points out that, for example, HIV/AIDS victims should have been provided with facilities to enable them to manage their situation as the majority of them lack basic health facilities. Based on the interactions I had with some of the people of Sierra Leone, their highest wish is to see the government respond to the root causes of the conflict by implementing the TRC recommendations. This would facilitate the reconciliation process.

\section{Dissemination of the TRC Report/findings}

The report and findings of the TRC were meant to inform and sensitise Sierra Leoneans on the real causes of the conflict which would serve as a lesson to learn from. In this respect, the Commission recommended the widest possible dissemination of its findings. It also encouraged the production of popular versions and summaries of the report in different local languages. It further recommended the formation of dissemination committees to distribute the

4 Interview with an employee of the Special Court, Freetown, September 2006. 


\section{Proscovia Svärd}

report at local and national levels. The report was also to be used in workshops to promote dialogue and stimulate debate. The printed version of the report has not been made available to the average Sierra Leonean and even though it can digitally be accessed, the majority of Sierra Leoneans do not have access to computers or Internet facilities. The erratic supply of electricity throughout the country also makes access impossible for the few who might want to explore this possibility. Non-governmental organisations (NGOs) and the Human Rights Section of the United Nations Integrated Office in Sierra Leone (UNIOSIL) and civil society groups did their best to disseminate the TRC findings. ${ }^{5}$ It ought not to be the duty of the NGOs or civil society groups to replace governmental functions of this nature. A government institution ought to have been charged with the task of disseminating the TRC findings. Proper mechanisms ought to have been put in place to enhance countrywide dissemination.

A respondent who worked at the TRC Secretariat argued that the government and the international community did not do much to promote the dissemination of the TRC report. The SLPP government was said to have been utterly inept in supporting the TRC process and that it obstructed free access to the TRC archives by failing to implement the recommendation of the TRC regarding the archiving of its documents. ${ }^{6}$ When I interviewed one of the Sierra Leonean commissioners, he was of the view that the government had done what it could to help. He showed me a copy of the pictorial report which was supposed to have been part of the TRC report but which due to lack of funds was never published. It is my hope that those working with the TRC documentation will be in a position to retrieve a copy from the personal archives of those who were involved in the process, in order to make the TRC report complete. ${ }^{7}$ The International community supported the TRC, but its investment risks dissipation if the follow-up programmes and projects are not supported. The TRC process would have needed a follow-up institution or committee to ensure that important recommendations such as the dissemination of the TRC findings

5 Interview with a Swedish Researcher working on Sierra Leone, Sweden, February 2006.

6 Interview with the TRC lead Researcher while in Sweden, March 2006.

7 Interview with one of the TRC Commissioners, Freetown, March 2006. 


\section{A case study of the Sierra Leone Truth and Reconciliation Commission}

are implemented. ${ }^{8}$ The TRC finished its work in 2004 and this is 2009 but its findings have not yet been effectively disseminated.

\section{In the aftermath of the TRC}

The TRC concentrated on the establishment of the truth through the acknowledgement of wrong-doing by perpetrators and the testimonies from victims, and on the provision of restitution, and the rehabilitation of victims from the trauma they were subjected to. It also recommended that the government of Sierra Leone enhances forward-looking reforms to deal with these issues. However, after the completion of its mission, there was no follow-up institution/ committee to take over the work that was to follow. It was only on 11 December 2006 that a Human Rights Commission (HRCSL) was inaugurated - a statutory body that is funded partly by the Government of Sierra Leone and partly by the United Nations Peace Building Fund, and is charged with the responsibility to maintain human rights and also serve as a follow-up committee of the TRC. It has the challenge of holding the government accountable for the implementation of the TRC recommendations, to follow up the TRC process and to engage in the dissemination of the TRC findings (King 2007:1-4). According to an interview that I had with both the Chair and the Executive Secretary during my first and second visits to Freetown in March 2007 and September 2007, the HRCSL was working with many issues related to human rights including the sensitisation of the people on the Child Rights Bill and the Gender Bill. ${ }^{9}$

Given the long history of repression and impunity, the challenges before the Commission will require the government's engagement in financing its activities. The Commission is supposed to serve as 'a watchdog and a visible route through which people can access their rights' (Conflict Management and Development Associates et al. n.d.:136). According to the Paris Principles,

8 Interview with one of the TRC Commissioners, Freetown, March 2006.

9 Interview with the Chair and the Executive Secretary of the Human Rights Commission of Sierra Leone, September, 2007, Freetown, Sierra Leone. 


\section{Proscovia Svärd}

the HRCSL is supposed to be funded by the government of Sierra Leone. ${ }^{10}$ The Commission only became fully operational in 2008 (Human Rights Commission of Sierra Leone 2008:14). This is year 2009, but the HRCSL is still urging the new government of Sierra Leone, to set up a TRC Follow-Up Committee as recommended by the TRC (Human Rights Commission of Sierra Leone 2008:65). The TRC was sanctioned by the SLPP government of Tejan Kabbah, but it failed to link its reforms and reconstruction efforts to the TRC recommendations.

\section{The SLPP Government's efforts to bring about democratic change}

Post-conflict Sierra Leone has received tremendous amounts of money from the UK Department for International Development (DFID), the United Nations High Commissioner for Refugees (UNHCR), the United Nations Development Programme (UNDP) and the United Nations Mission in Sierra Leone (UNASMIL). The money was directed at repatriation, reintegration, rehabilitation and reconstruction (Freeman 2008:1). Freeman is of the view that some reconstruction efforts have been successful: like the resettlement of 300000 Sierra Leoneans, the disarmament of over 70000 ex-combatants, the extensive training of the police and restructuring of the military by the British, the construction of clinics, schools, and homes and the successful execution of free elections. However, despite these international efforts, the root causes of the conflict are still omnipresent and this is causing disillusionment among the population (Freeman 2008:2).

Zack-Williams (2008:13) argues that the SLPP government led by President Alhaji Ahmad Tejan Kabbah failed to deliver the dividends of democracy like basic amenities, employment and better infrastructure. However, according to an interview that I held in March 2007 with Dr. Ahmed Dumbuya, who was at that time the Presidential Advisor of the SLPP government, his view was that his government had taken a holistic approach in dealing with the challenges of postconflict reconstruction and had made the following achievements:

10 Interview with the Executive Secretary of the Human Rights Commission of Sierra Leone, Uppsala, February 2009. 


\section{A case study of the Sierra Leone Truth and Reconciliation Commission}

- The government carried out several institutional and governance reforms to strengthen government institutions in order to make the civil and public service delivery more effective.

- The decentralisation programme had reinstituted local government machinery and had brought the government closer to the people, which enabled them to participate in governance.

- Several reform measures had been put in place to improve the government's resource regulatory systems - because in the past, the country's minerals were accessed without sufficient scrutiny.

- A huge expansion in the education field through the provision of infrastructure for schools and two universities.

- More teachers were recruited and trained and the government provided subsidies for school fees at primary, secondary and tertiary level.

- The roads that were destroyed during the war have been repaired and so have many of the institutions.

- All 19 local government bodies have been reinstated and they are all being empowered in terms of funds to carry out services in their areas.

- In the justice sector, efforts have been made in infrastructural developments, such as the building of more court houses and the training of more magistrates and judges - because the delivery of justice was one of the problems that created the war. ${ }^{11}$

Dr. Dumbuya agreed that Sierra Leone is a country with a prosperous future because of its natural and human resources, and that the discrepancies which created the environment for the war, will have to be addressed through the development of resources that would improve the lives of the people. Despite the holistic approach that the SLLP government undertook, as argued by the Presidential Advisor, the majority of Sierra Leoneans are still living in abject poverty. My interview with one of the key actors at Fourah Bay College,

11 Interview carried out in Freetown, Sierra Lone with Dr. Ahmed Dumbuya, the former Presidential Advisor of the SLPP Government, in March 2007. 


\section{Proscovia Svärd}

University of Sierra Leone, revealed that a lot still needs to be done in Education, in order to keep up with the challenges of post-war reconstruction.

\section{Education and its challenges}

Education is a master instrument in transforming attitudes, social structures, acceleration of growth and the development of new political patterns. Article 25 of the Lomé Agreement pledged to 'promote human rights education, including the schools, the media, the police, the military and the religious community' (Hayner 2007:8). Hinton (2002) contends that the first post-independence educational system of Sierra Leone was elitist. It only focused on academic subjects and ignored technical and vocational training which would have enabled students to earn a living even as school drop-outs. Lack of nationbuilding educational policies led to mass illiteracy (Hinton 2002:109). Sierra Leone's education system needs to utilise the energies of the youth, and lack of the political will to do so will only hinder social and economic progress and will lead to political instability (Hinton 2002:111). 85\% of Sierra Leone's population is illiterate (Hinton 2002:5). Women represent the largest group without formal education (Conflict Management and Development Associates et al. n.d.:174).

A decade of armed conflict and political unrest affected the entire infrastructure of Sierra Leone including schools. The Fourah Bay College respondent bemoaned the state in which the universities are. He argued that the international donors are not interested in supporting tertiary education and that the University of Sierra Leone is facing enormous challenges in meeting the students' demands. In order to enable the students to actively participate and to get sensitised about the realities of the day, as the country transits from war to peace, the university has to respond to the national challenges of state reconstruction and challenges from regional and international dimensions. He enumerated the present challenges as follows:

- Lack of up-to-date equipment to enhance the research capacity of students as well as members of staff.

- $\quad$ Lack of infrastructure.

- The university library's dire need to update its collections of books and its Internet facilities. 


\section{A case study of the Sierra Leone Truth and Reconciliation Commission}

- Lack of research capacity for staff - lack of access to research materials and avenues to disseminate their research findings.

- The brain drain syndrome both before and after the war has resulted in the loss of a number of qualified lecturers and professors who left the university for other jobs or better conditions of service in the Diaspora.

The faculty of Social Sciences and Law should therefore be instrumental in the national and regional transformation and the courses offered should reflect the realities of the nation, the region and the international community. Tertiary education is however de-emphasised by the international funders and since the SLPP government was getting $60 \%$ of its funds from the international community, its hands were tied behind its back and it was therefore unable to respond to the challenges of the university. He stressed that education is a human right and the only way for Sierra Leoneans to move forward since only $35 \%$ of the population is considered literate. Schools and universities are key players in knowledge generation and dissemination and this requires research in post-conflict challenges. The international community should review and revisit some of the International Monetary Fund (IMF) conditionalities for the paging of the number of teachers and lecturers to be hired. This has created problems because in post-conflict societies, universities have to respond to post-conflict challenges in education and have to introduce new programmes and subjects related to trauma healing, post-conflict reconstruction and reconciliation issues which will contribute to the reconstruction of such societies. According to him, Sierra Leone, a country emerging from war, has only one psychiatric doctor.

My respondent was of the view that Sierra Leone needs more investment into university education and the government also has to utilise the resources of the state judiciously, to ensure that education is given the priority it deserves in order to increase the country's capacity for development. The media play an indispensable role in educating the electorate and therefore the TRC made recommendations to enhance their activities.

\section{TRC media recommendations}

In democratic societies the media play an informative role and disseminate information on complex issues to the general public. The media's interpretation 


\section{Proscovia Svärd}

of conflicts or particular situations usually defines public knowledge and constructs public opinion on that conflict or issue (Curran 2000:127). The TRC called upon the Sierra Leone Association of Journalists (SLAJ) and the Independent Media Commission (IMC) to be more proactive in advancing the culture of human rights in Sierra Leone (Conflict Management and Development Associates et al. n.d.:132). It also encouraged the media houses to carry out thorough investigations before publishing stories, in order to offer informed accounts on matters of both national and international interest to the public. The Commission advocated media freedom as key to the enhancement of democracy and reconciliation.

The media however still have problems that are posed by the various sections of the Public Order Act which limits the freedom of expression. The use of sedition and defamation proceedings limits media operations (Conflict Management and Development Associates et al. n.d.:131). According to an interview with the Chairperson of SLAJ, the Public Order Act ought to be reviewed because it criminalises journalism as a profession and is inconsistent with the whole concept of democracy, because it impinges on the rights of freedom of expression. He was of the view that the Public Order Act interferes with the freedom of intellectual development and that even though reliable information is important, the laws do not allow public officials to talk to journalists or to give them information. The information the press therefore gets, is either accidental or stolen. It is anticipated that the new constitution under review, will promote access to information. ${ }^{12}$

\section{Conclusion}

Truth Commissions have become part and parcel of the peace agreements that are internationally signed, and given the nature of the conflicts, they play a very important role. Through the support of the international community the SLPP government sanctioned the establishment of a TRC - a platform created to bring together both victims and perpetrators to recount their experiences

12 Interview with the Chairman of the Sierra Leone Journalist Association in Freetown, Sierra Leone, March 2007. 


\section{A case study of the Sierra Leone Truth and Reconciliation Commission}

of the conflict. This was an effort to acknowledge the horrendous atrocities that were committed against the civilian population and to enhance healing and reconciliation. As argued by some of the authors, reconciliation is key if a post-conflict society is to move forward and reconstruct every facet of its system for the attainment of a just and democratic society. The new democratic dispensation therefore ought to deliver the dividends of democracy, in the form of basic amenities, freedom of expression, and security. The people, who have experienced a long and brutal armed conflict and repressive governments since independence, need to quickly see positive developments. Democracy is, as illustrated by the different authors, a conflict management system. It builds on respect for human rights, institutional arrangements for power sharing, checks and balances for the responsible and accountable use of power, and process options for public policy which meet local needs for development and human security, political participation and development, and prevailing peace.

A sum of 4,6 million US dollars was invested by the international community in the TRC but the follow-up activities are slow in being implemented. The issue is: how long should the victims of war wait in order to see an improvement in their daily lives? Even though the SLPP government as argued by its Presidential Advisor, tried to address some of the causes of the conflict, the interviews show that the root causes of the conflict remain unaddressed and the reparations have not yet been paid out. Where the SLPP government instituted some changes, it failed to link them to the TRC recommendations. This raises questions, especially since the government was party to the Agreement that led to the establishment of the TRC. The dissemination of the TRC findings that was meant to educate the masses and prevent a recurrence of the conflict was left to the civil society groups and the NGOs. The Human Rights Commission of Sierra Leone that was to follow-up the TRC process was only established two years after the TRC had finished its work. It is now fully operational and has done commendable work. But it is still dependent on international assistance in order to carry out its activities even though the Paris Principles state that it should be financed by the state.

The eradication of the culture of impunity and the restoration of respect for human rights will require an investment in long-term education. It is argued 


\section{Proscovia Svärd}

in the TRC report that lasting peace will have to build on an understanding of the past and comprehensive knowledge of the nature of the conflict. Schools therefore ought to include the TRC findings in their curricula and universities ought to introduce courses that would address issues related to post-conflict trauma, peacebuilding and democratic consolidation. However, without the proper financial assistance, equipment and infrastructure this is going to be an enormous challenge for a post-conflict state like Sierra Leone.

The media have an important role to play in a democratic society and therefore freedom of expression is key to the enhancement of a vibrant public sphere. The laws impeding media freedom ought to be abolished since they curtail the media's 'watch dog' role of keeping an eye on how those elected into government offices are managing the public goods. Media independence is essential to the democratic development of the society through information dissemination.

TRCs engage in deep research on which their recommendations are based. However, despite all this indispensable work, research shows that the plight of the marginalised in most places where TRCs have been implemented has not been addressed and that the final reports have not sufficiently been disseminated. The government of Sierra Leone will therefore have to honour its citizens by implementing the TRC recommendations. There is a school of thought that proposes the use of traditional mechanisms, since they might be a less expensive alternative that might enhance ownership. However, the nature of the conflicts makes it difficult to find a neutral ground that could reconcile victims and the perpetrators. The issue is debatable, but the TRC alternative needs to be seriously evaluated in order to deliver the marginalised and traumatised populations from a life of endless suffering and poverty.

\section{Recommendations}

Lessons drawn from this study could be useful for the establishment of future truth commissions. The international community needs to invest in a longterm reconciliation process that will bring about sustainable peace. Follow-up activities are crucial to the legitimacy of the TRC process and should therefore be immediately pursued in order to deliver the people from the state of despair. 


\section{A case study of the Sierra Leone Truth and Reconciliation Commission}

The international community needs to start asking whether TRCs are working for the poor. Is the promise to deliver individual reparations realistic or should the focus be moved onto community reparations? Failure to deliver reparations to the marginalised groups risks endangering the prevailing precarious peace. A mini-commission should be established with a particular focus on the follow-up activities. It should be under the Human Rights Commission of Sierra Leone with a special budget to engage in the dissemination of the findings and to dialogue with the government on the implementation of the recommendations. The funding from the international community should be stepped up, so that the pending issues can be dealt with. The documentation of the TRC is a good example to illustrate the need for more support of the process in order to enhance local ownership, access to the TRC findings and the building of institutions that would preserve and disseminate the findings. In a country where information institutions are poorly equipped and where there is lack of access to Information Communication Technologies, low levels of education and lack of the political will to make information available to the people, the international community should invest in an information infrastructure at the beginning of the commission's work that would promote access to the TRC findings.

People need to see that the TRC recommendations are implemented because it gives legitimacy to the process. This would require well-established local and national institutions with the capacity to support the process. This further illuminates the need for local capacity building as a way to ensure ownership of the reconciliation process. Local capacity can act as stimulus for the more rapid development of democratic procedures required for nation building. National and local initiatives for reconciliation should be promoted to transform the culture of impunity. Support to long-term education and especially tertiary education is crucial to addressing the culture of impunity. Access to information is also an important part of education since it enlightens the citizens about the different aspects of their society. Therefore, Freedom of Information (FOI) Laws should be enacted in order to create an engaged public sphere. 


\section{Proscovia Svärd}

\section{Sources}

Afrol News n.d. Afrol background - The civil war in Sierra Leone Available from: <http://www. afrol.com/News/si1007_civil_war.htm> [Accessed 20 March 2007].

Avruch, Kevin and Beatriz Vejarano 2002. Truth and Reconciliation Commissions: A review essay and annotated bibliography. The Online Journal of Peace and Conflict Resolution 4 (2), pp. 37-76. Available from: <www.trinstitute.org/ojpcr/4_2recon.pdf> [Accessed 14 March 2006].

Brahm, Eric 2006. Truth commissions. Available from: <http://www.beyondintractability.org/ essay/truth-commissions/> [Accessed 26 June 2006].

Conflict Management and Development Associates, Witness, and Campaign for Good Governance n.d. TRC Report for ease of reference and research: The essential excerpts.

Curran, James 2000. Rethinking media and democracy. In: Curran, James and Michael Gurevitch eds. Mass media and society. New York, Oxford University Press.

Dumbuya, Lansana 2003. The Truth and Reconciliation Commission in post conflict Sierra Leone. LL.M. dissertation submitted to the Faculty of Law, University of Pretoria. Available from: <https://www.up.ac.za/dspace/bitstream/2263/988/1/dumbuya_1_1.pdf> [Accessed 20 March, 2007].

Freeman, Christi F. 2008. The failures of post-conflict reconstruction in Sierra Leone and the threat to peace. Available from: <http://www.beyondintractability.org/case_studies/ reconstruction_sierra_leone.jsp?nid...> [Accessed 9 May 2009].

Gloppen, Siri 2005. Roads to reconciliation: A conceptual framework. In: Skaar, Gloppen and Suhrke 2005.

Hayner, Priscilla 2002. Unspeakable truths: Facing the challenge of truth commissions. New York and London, Routledge.

Hayner, Priscilla 2004. The Sierra Leone Truth and Reconciliation Commission: Reviewing the first year. International Centre for Transitional Justice, Case Study Series.

Hayner, Priscilla 2007. Negotiating peace in Sierra Leone: Confronting the justice challenge. Report, Centre for Humanitarian Dialogue and International Centre for Transitional Justice. Geneva: Centre for Humanitarian Dialogue.

Hinton, Samuel 2002. University student protests and political change in Sierra Leone. New York, The Edwin Mellen Press.

Human Rights Commission of Sierra Leone 2008. The state of human rights in Sierra Leone. Freetown, Human Rights Commission of Sierra Leone

Human Rights Watch 1991. Human Rights Watch world report: An annual review of developments and the ... administration's policy on human rights worldwide. New York, Human Rights Watch. 


\section{A case study of the Sierra Leone Truth and Reconciliation Commission}

International IDEA (Institute for Democracy and Electoral Assistance) 2006. Democracy, conflict and human security: Pursuing peace in the $21^{\text {st }}$ century. Laholm, Sweden, Trydells Tryckeri AB.

Keen, David 2005. Conflict and Collusion in Sierra Leone. New York, Palgrave.

King, Jamesina 2007. Presentation by the Human Rights Commission of Sierra Leone (HRCSL) to His Excellency the President Ernest Bai Koroma. Available from: <http:news.sl/ drwebsite/publish/article-20056863.shtml> [Accessed 20 April 2008].

Lomé Accord - 7 July 1999, Peace Agreement between the Government of Sierra Leone and the Revolutionary United Front of Sierra Leone. Available from: <http://www.sierra-leone. org/lomeaccord.html> [Accessed 23 February 2006].

Othman, Mohamed 2005. Justice and reconciliation. In: Skaar, Gloppen and Suhrke 2005.

Rothstein, Bo 2005. Trust, corruption and political institutions. In: Collegium for Development Studies, Political corruption and democracy - The role of development assistance. Utsikt mot Utveckling 23, pp.19-27. Uppsala, Collegium for Development Studies, Uppsala University.

Rudebeck, Lars 2002. On the twofold meaning of democracy and democratisation. In: Collegium for Development Studies, Democracy, power and partnership - Implications for development co-operation. Utsikt mot Utveckling 17, pp. 3-12. Uppsala, Collegium for Development Studies, Uppsala University.

Sawyer, Amos 2004. Governance and democratization. In: Adebayo, Adekeye and Rashid Ismail eds. West Africa's security challenges: Building peace in a troubled region. Boulder CO, Lynne Rienner Publishers.

Sawyer, Edward and Tim Kelsall 2007. Truth vs justice? Popular views on the Truth and Reconciliation Commission and the Special Court of Sierra Leone. The Online Journal of Peace and Conflict Resolution 7 (1), pp. 36-68.

Schabas, Williams. A. 2005. The Sierra Leone Truth and Reconciliation Commission. In: Skaar, Gloppen and Suhrke 2005.

Scott, Jerome and Walda Katz-Fishman 2004. Popular democracy a vision for our movement. What should popular democracy look like? Available from: <http://www.zmag.org/ content/showarticle.cfm?ItemID $=6498>$

Sesay, Amadu ed. 2003. Civil wars, child soldiers and post conflict peace building in West Africa. Lagos, College Press.

Sesay, Amadu 2007. Does one size fit all? The Sierra Leone Truth and Reconciliation Commission revisited. Discussion Paper 36. Stockholm, Elanders Gotab AB.

Skaar, Elin, Siri Gloppen and Astri Suhrke eds. 2005. Roads to reconciliation. Lanham MD, Rowman and Littlefield.

Törnquist, Olle 2003. Assessing problems and options of democratisation. In: Collegium for Development Studies, Democracy as actual practice: What does democracy really bring? 


\section{Proscovia Svärd}

Utsikt mot Utveckling 20, pp. 31-43. Uppsala, Collegium for Development Studies, Uppsala University.

Truth and Reconciliation Commission of South Africa 2003. Truth and Reconciliation Commission of South Africa Report, 2003. Available from: <http://www.info.gov.za/ otherdocs $/ 2003 / \operatorname{trc} />$

Ukeje, C. 2003. Sierra Leone: The long descent into civil war. In: Sesay 2003.

Zack-Williams, A.B. 2008. Introduction: The quest for sustainable development and peace. In: Zack-Williams, A.B. ed. The 2007 Sierra Leone elections. Stockholm, Elanders Sverige AB. 